\title{
Political Philosophy and Business Ethics
}

\section{Affiliation}

Cristina Neesham

Senior Lecturer

Swinburne University

Melbourne, Australia

\author{
Rob Macklin \\ Senior Lecturer \\ University of Tasmania \\ Hobart, Australia
}

\section{Synonyms: \\ Political science \\ Political theory \\ Governance \\ Professional ethics \\ Normative ethics}

\section{Definition and Introduction}

In this discussion, we consider political philosophy as a branch of philosophy studying the way human communities and societies create and maintain various forms of governance for the good of constituent individuals and groups. Governance as a system of conducting the affairs of the polis, i.e., the participating community of citizens, is the basis of society's political life. Hence, political philosophy is the practice of thinking reflectively about the nature of governance, political institutions and power, understood as a constitutive factor in the relationship between governing and being governed.

Ontologically, political philosophy is concerned with the nature of political systems and relations, and of the values and principles that may be governing them. Epistemologically, the focus of political philosophy is on the role of knowledge and ideas in structuring people's understanding of political purpose, legitimacy, and authority. Allied with normative ethics, political philosophy engages in appraisals of past and existing governance arrangements and their impact on the wellbeing of societies, communities and individuals - by reference to some ideal of the good. It also conceptualizes and evaluates proposals for the future of human communities and societies, using normative principles such as justice, rights, needs, equality, desert, responsibility, freedom, and life chances.

Topics of central interest in political philosophy include:

- The (tacit or explicit) social contract between citizens in a polis, as a fundamental principle that makes social and political order possible;

- Forms of government of the polis, in particular the sources and principles of governing citizens, and the use of power and statecraft in international relations;

- Private and public property, and the rights and responsibilities that governments have in relation to both;

- The rights and liberties, duties and obligations of citizens, as well as how citizenship is defined and articulated;

- Authority and legitimacy, i.e., their nature, forms and grounds, and their manifestation in various political orders, from democracy to totalitarianism; and

- The role of public discourse and ideology in structuring political relationships and outcomes in a community.

As a key political influencer and decision maker, business plays an increasingly important role in shaping today's mainstream philosophical perspectives on how communities, local, national and global, should be governed. It is therefore imperative that the ethics of 
business practices be informed, as much as possible, by the most advanced and enlightened thinking political philosophy has to offer.

\section{Description}

The business ethics literature has sought to address and apply all the topics mentioned above in order to illuminate the mutually influencing relationship between business and the polis. For example, it has discussed: business as bound by social contracts; corporate governance as a political process mirroring those practised in the wider society; interactions between private property and labour as sources of capital, and issues of corporate ownership; corporations as citizens and the nature of corporate citizenship; corporate legitimacy and authority, and the scope and limits of democracy in organizations; and organizations as networks of power relations and loci of ideological control. The main arguments raised in each of these discussions are outlined below.

\section{Social contracts, hypernorms and business ethics}

The social contract is a core concept in political philosophy, developed by a long series of prominent thinkers - from Hobbes (1651), Locke (1689) and Rousseau (1762) to Rawls (1971) and Gauthier (1986), among others. The notion of a social contract, understood as a nexus of implicitly agreed norms by which people (individuals and groups) live together in society, has for centuries provided a framework for explaining and justifying: (1) what private interests should be sacrificed in order to promote more fundamental liberties for all citizens; and (2) why more comprehensive forms of governing structures (such as governments) should be accepted, in order to oversee and enforce such norms. Inspired by this tradition, Donaldson and Dunfee (1994) established an integrative social contracts theory (ISCT) as a normative theory of ethics in and for business. The application of ISCT to business activity helps us identify and understand the 'ties that bind' businesses - in other words, their social, political and moral obligations to the wider community and its citizens. The theory is integrative because it articulates microsocial contracts, i.e., agreements on ethical behaviour in business, as established between members of a particular economic community, with macrosocial contracts, i.e., hypothetical agreements on how economic activities should be carried out using moral norms that belong to the wider community. Further, the norms that emerge through genuine agreement between businesses as economic agents in a particular context are bound by universal moral principles called hypernorms, which set the ethical criteria for evaluating all other norms.

ISCT has gained wide acceptance across business ethics. However, some commentators argue that ISCT, like other social contract approaches, places too much reliance on the assumption that moral reasoning can be free of the encumbrances of everyday life (Frederick 2000). A variety of alternatives has been proposed, including communitarian, discourse and dialogic approaches contending that political reasoning cannot be abstracted from historically embedded cultural values and norms (Macklin and Mathison 2017).

\section{Corporate governance as political process}

Discussions of corporate governance go to the purposes of organizations and how they should be governed in pursuit of these purposes. Increasingly, relevant analogies are drawn between governing organizations and governing nation states, societies and markets. Specific to corporations, of significant concern is the political role and status of shareholders. The orthodox position identifies the maximization of shareholder value as the primary principle of 
governance (Cragg and Matten 2011). Nevertheless, increasing numbers of authors are challenging any sole focus on shareholder supremacy, arguing that managers have ethical duties towards a range of other stakeholders, including employees, consumers and the environment (Freeman et al. 2010). These discussions raise questions of principle about the responsibility that senior managers and boards have towards potentially vulnerable groups.

\section{The role of property and labour as sources of capital and corporate ownership}

Allied to discussions of corporate governance is a debate that involves business ethics in the relationship between labour and capital. The question of what governance role and rights employees should have in an organization has been raised following observations about the dominance of capital owners, rather than labour owners, in governing the productive organization. Traditional conceptions of corporate governance support a share-ownership model for justifying governing power - to the extent that, if employees are to be involved in the governance of the firm, they should be shareholders (Jensen and Meckling 1979). Alternative arguments (see Boatright 2004) use the language of political rights to cast ownership as attaching to a right to the revenue produced by organizational activity. As labour power is an asset that employees invest in firms, it implies ownership and, as such, a right to some share of revenue. Primarily, employees exercise a governance role through their right to shape the terms and conditions of their employment.

Opposing the liberal tradition of political economy, Marxist labour process theory (LPT) reverts the capital-labour balance in the ownership debate almost entirely in favour of labour, emphasizing its central role in generating revenue and ultimately driving economies. According to Marx (1867), and later LPT, a logic of capital accumulation drives owners of capital to continually seek new ways to produce goods and services more effectively and efficiently. This urge to revolutionize the labour process is portrayed as driven by incessant competition between capitalists, as well as between capital and labour. Because of the indeterminacy of labour, employees can, however, resist efficiency drives and act autonomously. Consequently, owners of capital through the agency of managers will continually seek new ways to control the activities of labour (Thompson and Vincent 2010). Given employers' relative power vis-à-vis employees, this results not only in the exploitation of workers but also in ongoing structural antagonism between capital and labour. To understand and improve on current corporate governance arrangements in capitalism, it is therefore important to examine how the frontiers of capital's control of labour at the workplace are constructed and sustained (Edwards 2010). Ethical managers, therefore, not only have to make decisions that uphold workplace justice and mitigate the effects of exploitation but also have to face up to this structural antagonism as an ongoing source of workplace conflict and ethical dilemmas.

\section{Corporate citizenship: political theories of corporate social responsibility}

Applications of political philosophy to organizations, industries and markets portray corporations as types of political communities requiring strategies and techniques aimed at internal governance. An emergent body of literature focuses on the outward-facing political role of corporations in global and societal governance. Whilst organizations have often been regarded as political actors in societies, alongside other groups such as trade unions and community groups, they have usually been considered as primarily independent from the state. In western democracies, the state tends to be cast in the role of governing pluralist societies for the greater good, which requires that it should mediate the contending claims of different groups, including corporations. 
However, the once-clear division between the economic role of business and the political role of the state is now blurred. It is argued that business firms, driven in part by globalization, are increasingly taking on governance tasks in and across societies. The erosion of the nation state's capacity to regulate economies, particularly given the influence of globalized financial markets, is creating a gulf that corporations are voluntarily seeking to fill. By doing so, they attempt to regulate their activities and pursue ends in ways that contribute to the common good. This development has been named political CSR (Scherer et al. 2014).

Political CSR cannot be seen in purely instrumental terms: in some cases, corporations are acting as social innovators for the public good, and not just pursuing private interests narrowly and simplistically conceived. However, the emerging role of corporations in the polis raises important questions about the risk posed by current corporate governance structures to democracy and democratic institutions (Scherer et al. 2014). With respect to this risk, both Friedman's warnings about the ability of corporations to competently pursue non-economic ends (1970), and Marxist-inspired arguments that fundamentally question the genuine interest of multinational corporations in leading the way towards the public good, become relevant.

\section{Corporate legitimacy, authority and democracy}

In political philosophy, legitimacy is defined as adherence to voluntarily (albeit often tacitly) agreed norms of social, political and moral behaviour by those who are to live by these norms. Public authority, such as that of government over its citizens, is then justified on the basis of such norms (Rossi 2014). Legitimacy is the foundation of laws, which in turn combine with the free, voluntary support of the citizens to confer on the state the authority it requires in order to govern. One of the recurrent questions political philosophy has sought to answer is: what form of social-political order (and therefore government) is most appropriate for maintaining an optimal relationship between legitimacy and authority? In theory at least, democracy has been preferred to autocratic government (Keane 2009).

Applied to the ethics and social responsibility of business, the concepts of legitimacy and authority have been discussed in relation to principles of discourse ethics and deliberative democracy, as outlined through Habermas's (1987) theory of communicative action. Corporate legitimacy is thus analyzed as the outcome of deliberation processes whereby the purpose of achieving legitimacy should be moral (i.e., providing strong reasons for a foundational social good) rather than cognitive (i.e., satisfying public perceptions) or pragmatic (i.e., satisfying powerful stakeholders). In line with this purpose, corporations (multinationals in particular) are increasingly expected to engage in public justifications of their actions in a permanent dialogue with society and its stakeholders (Palazzo and Scherer 2006). Corporate executives are therefore drawn to reflect on ethical questions that are closer to political philosophy than to business management. A key skill of the executive resides in integrating the two and translating this hybrid perspective into coherent, legitimate, successful corporate action.

\section{Power relations, governmentality and corporate ideology}

The role of power in social and political relations has been a constant preoccupation in political philosophy. For contemporary theories of organizational management and control, Foucault's concepts of pastoral power (2000), disciplinary power (1975) and governmentality (1991) are seminal. His ideas have provided business ethics thought (as well as related empirical research) with a solid theoretical foundation for exploring the impact of institutionalized forms of power on individual autonomy, the construction of the subject in organizations (especially through ideology and discourse), and the diffusion of governing action through socially accepted forms of knowledge and self-correction. In this context, ethics is not about enforcing the 
organization's institutionalized norms of subject construction: on the contrary, it is the space where critical reflection on such constructions and norms, by managers and subordinates alike, becomes possible and, consequently, it is the source of emancipatory change in power relations and business practices (see Ibarra-Colado et al. 2006).

Foucault-inspired investigations of dominant ideologies in organizations, advanced by critical management studies, have also led to new developments in business ethics. For example, human resource management research has been found to adhere to unitarist assumptions that portray organizations as sites of consensus and common objectives, editing out possibilities of legitimate discord and conflict (Geare et al. 2006; Greenwood and Van Buren 2017). Unitarism is not only an all-encompassing ideological framework determining how employers and employees do, can and should understand and conduct their relationship. It also prevents researchers from challenging the foundations of their own theoretical frameworks, and distorts the scope and limits of business ethics in both theory and practice.

\section{Summary}

Theories and arguments advanced in political philosophy have often shaped central ideas and debates in business ethics. Furthermore, philosophical explorations of concepts such as autonomy, responsibility, power, ownership, justice, rights and discourse in the context of organizations and workplaces embedded in local, national and global communities are likely to continue, to the benefit of both domains. Discussions of ISCT and its alternatives provide nuanced approaches to grounding political and moral norms in organizations, offering a fertile context of application for political theories. Philosophical questions about governance and ownership continue to shape analytical and normative discussions of how organizations in capitalist economies are and should be regulated. The emergence of political CSR and a political role for business executives can be seen as highlighting the centrality of corporations to the governance of global concerns such as poverty and the environment. Despite a widespread application of philosophical notions of power, ideology and discourse in the study of management and organizations, business ethics as a critical field of inquiry is yet to develop an appropriate space for engaging with more recent, alternative advances in political philosophy - in particular, those adopted and developed in the emancipatory programs of feminist and postcolonialist research.

\section{Cross-references:}

Corporate citizenship

Corporate governance

Corporate social responsibility

Marxism

Property rights

Role of philosophy in business ethics

\section{References}

Boatright, J.R. 2004. Employee governance and the ownership of the firm. Business Ethics Quarterly 14(1): 1-21.

Cragg, W., and D. Matten. 2011. Ethics, corporations, and governance. Journal of Business 
Ethics 102(1): 1-4.

Donaldson, T., and T.W. Dunfee. 1994 Toward a unified conception of business ethics: Integrative social contracts theory. Academy of Management Review 19(2): 252-284.

Edwards, P.K. 2010. Developing labour process analysis: Themes from industrial sociology and future directions. In Working life: Renewing labour process analysis, ed. P. Thompson and C. Smith, 29-46. Houndmills: Palgrave.

Foucault, M. 1975. Discipline and punish: The birth of the prison. New York: Vintage Books.

Foucault, M. 2000. Power. The essential works of Foucault (vol. 3). New York: The New Press.

Foucault, M. 1991. Governmentality. In The Foucault effect: Studies in governmentality, ed. G. Burchell, C. Gordon and P. Miller, 87-104. Chicago: University of Chicago Press.

Freeman, R.E., J.S. Harrison, A.C. Wicks, B.L. Parmar, and S. De Colle. 2010. Stakeholder theory: The state of the art. Cambridge: Cambridge University Press.

Friedman, M. 1970. The social responsibility of business is to increase its profits. The New York Times Magazine, 13 September.

Gauthier, D. 1986. Morals by agreement. Oxford: Oxford University Press.

Geare, A., F. Edgar, and I. McAndrew. 2006, Employment relationships: Ideology and HRM practice. International Journal of Human Resource Management 17(7): 1190-1208.

Greenwood, M., and H.J. Van Buren III. 2017. Ideology in HRM scholarship: Interrogating the ideological performativity of 'new unitarism'. Journal of Business Ethics 142(4): 663-678.

Habermas, J. 1987. The theory of communicative action. Boston, MA: Beacon Press.

Hobbes, T. 1651/2009. Leviathan. Oxford: Oxford University Press.

Ibarra-Colado, E., S.R. Clegg, C. Rhodes, and M. Kornberger. 2006. The ethics of managerial subjectivity. Journal of Business Ethics 64(1): 45-55.

Jensen, M.C., and W.H. Meckling. 1979. Rights and production functions: An application to labor-managed firms and codetermination. Journal of Business 52: 469-506.

Keane, J. 2009. The life and death of democracy. London: Simon and Schuster.

Locke, J. 1689/1980. The second treatise of government. Indianapolis, IN: Hackett Publishing.

Macklin, R., and K. Mathison. 2017. Embedding ethics: Dialogic partnerships and communitarian business ethics. Journal of Business Ethics, First Online, January: 1-13. doi:10.1007/s 10551-016-3431-0

Marx, K. 1867/1995. Capital (vol. 1). Oxford: Oxford University Press. 
Palazzo, G, and A.G. Scherer. 2006. Corporate legitimacy as deliberation: A communicative framework. Journal of Business Ethics 66(1): 71-88.

Rawls, J. 1971. A theory of justice. Oxford: Oxford University Press.

Rossi, E. 2014. Legitimacy, democracy and public justification: Rawls' political liberalism versus Gaus' justificatory liberalism. Res Publica 20(1): 9-25.

Rousseau, J.J. 1762/2003. On the social contract. Mineola, NY: Dover Publications.

Scherer, A.G., G. Palazzo, and D. Matten. 2014. The business firm as a political actor: A new theory of the firm for a globalized world. Business \& Society 53(2): 143-156.

Thompson, P., and S. Vincent. 2010. Labour process theory and critical realism. In Working life: Renewing labour process analysis, ed. P. Thompson and C. Smith, 47-69. Houndmills: Palgrave Macmillan. 